\title{
Peran key opinion leader dalam strategi public relations pada komunikasi krisis perusahaan
}

\author{
Dini Yuanita \\ Universitas Indonesia, Jakarta, Indonesia
}

\begin{abstract}
ABSTRAK
Krisis dapat merusak reputasi perusahaan jika tidak ditangani dengan strategi komunikasi krisis yang tepat. Public relations (PR) bertanggungjawab dalam menentukan strategi komunikasi krisis perusahaan. Kemunculan media sosial membuat potensi krisis merambah ke krisis media sosial. Social mediated crisis communication (SMCC) merupakan model strategi komunikasi krisis yang melibatkan media sosial dan atau media tradisional dan komunikasi word of mouth (WOM) secara online dan offline. Penelitian ini bertujuan untuk mengkaji peran Key Opinion Leader (KOL), waktu respons krisis serta bentuk pesan dan cara penyampaian informasi krisis pada strategi komunikasi krisis perusahaan menggunakan model SMCC, Penelitian ini menggunakan metode pendekatan kualitatif dengan jenis deskriptif. Wawancara mendalam dilakukan kepada tiga orang informan yang dipilih melalui teknik purposive sampling, dengan kriteria praktisi PR perusahaan berpengalaman minimal 25 tahun dan memiliki pengalaman serta pengetahuan tentang komunikasi krisis perusahaan. Hasil penelitian mengatakan bahwa KOL pada strategi PR perusahaan berperan sebagai sekutu perusahaan dalam meneruskan informasi krisis perusahaan kepada publiknya, terutama saat publik sedang memiliki ketidakpercayaan terhadap perusahaan. Perusahaan harus dapat merespons krisis paling lambat 12 jam pertama sejak krisis muncul agar dapat meminimalisir akibat krisis. Pemilihan media pesan harus disesuaikan dengan asal krisis mencuat. Informasi yang disampaikan harus transparan, jujur dan berkelanjutan menggunakan metode penyampaian storytelling. Temuan menarik pada penelitian ini adalah bahwa KOL pada model SMCC terdapat dalam media sosial, namun KOL seperti tokoh masyarakat juga menjadi pihak ketiga yang dapat mendukung keberhasilan komunikasi krisis. Selain itu penyampaian pesan storytelling juga berperan penting untuk dapat menenangkan masyarakat dan agar pesan dapat dipahami secara lebih komprehensif.
\end{abstract}

Kata-kata Kunci: Key opinion leader; komunikasi krisis; perusahaan; public relations; social mediated crisis communication

\section{Role of key opinion leaders in public relations strategy's corporate crisis communication}

\section{ABSTRACT}

A crisis could damage a company's reputation if it is not well managed with the right crisis communication strategy. Public relations (PR) is responsible for determining a company's crisis communication strategy. The emergence of social media has made the potential for a crisis escalating into a social media crisis. Social mediated crisis communication (SMCC) is a crisis communication strategy model that involves social media and/or traditional media and online/offline word of mouth (WOM) communication. This study examines the Key Opinion Leader (KOL) role, crisis response time, messages form, and ways of delivering crisis information in the company's crisis communication strategy by using the SMCC model. This study uses a qualitative approach with a descriptive method. In-depth interviews were conducted with three informants, selected through purposive sampling technique, with criteria includes corporate PR practitioners with at least twenty-five years of experience and having experience and knowledge of corporate crisis communication. The study results indicate that KOL in the company's PR strategy acts as an ally of the company in transmitting company crisis information to the public, especially when the public distrusts the company. Companies must respond to a crisis no later than the first twelve hours since the crisis arose to minimize the impact of the crisis. The choice of message for media must be adjusted to the origin of the crisis. The information submitted must be transparent, honest, and sustainable using the storytelling method of delivery. An interesting finding in this study is that KOL in the SMCC model is contained in social media, but KOL, like community leaders, becomes third parties who can successfully handle communication crises. In addition, the delivery of storytelling messages also plays a vital role in calming the community and that the message can be understood comprehensively.

Keywords: Key opinion leader; crisis communication; company; public relations; social-mediated crisis communication

Korespondensi: Dini Yuanita, SE.,SS., Universitas Indonesia. Gedung IASTH Lt.6, Kampus UI Salemba, Jl. Salemba Raya 4, Jakarta 10430.Email: deen.yuanita@gmail.com 


\section{PENDAHULUAN}

Perusahaan yang sukses memiliki aktivitas bisnis berjalan lancar dan reputasi baik di mata para stakeholder nya. Reputasi dihasilkan dari kerja keras public relations perusahaan dalam menjaga harmonisasi komunikasi internal dan eksternal perusahaan. Namun, setiap hari perusahaan menghadapi berbagai macam potensi krisis. Coombs mendefinisikan krisis sebagai peristiwa yang tidak dapat diprediksi yang mengancam harapan penting dari para pemangku kepentingan dan sangat berpengaruh kepada kinerja organisasi dan cenderung memberikan hasil negatif (Coombs, 2015). Secara umum, terdapat tiga elemen umum untuk mengkategorikan sebuah peristiwa sebagai sebuah krisis, yaitu terdapat ancaman, kejutan, dan waktu pengambilan keputusan yang singkat (Mikušová \& Horváthová, 2019).

Krisis dibagi menjadi dua jenis yaitu krisis organisasi dan bencana. Yang membedakan keduanya adalah bencana bisa menyebabkan krisis yang mengacaukan sistem terjadi dalam skala besar, berbahaya dan membutuhkan tindakan dari berbagai unit pemerintah, dan juga dapat mengakibatkan krisis pada perusahaan, misalnya, sebuah organisasi mungkin perlu menanggulangi dampak bencana pada operasional organisasinya. Sedangkan Implikasi yang terjadi pada perusahaan yang didera krisis adalah kerusakan kinerja dan reputasi perusahaan (Coombs, 2015).

Bicara reputasi perusahaan, reputasi sendiri dalam Kamus Merriam-Webster didefinisikan sebagai kualitas atau karakter keseluruhan seperti yang dilihat atau dinilai oleh orang pada umumnya, tempat untuk dihargai atau dihormati publik: nama baik (Patrick \& Adeosun, 2013). Dalam dunia korporat, Fombrun menggambarkan reputasi perusahaan sebagai representasi persepsi tindakan masa lalu perusahaan dan prospek masa depan yang menggambarkan daya tarik perusahaan secara keseluruhan untuk semua konstituen utamanya bila dibandingkan dengan pesaing utama lainnya (Fombrun, 2018). Ahli lain mengatakan bahwa reputasi perusahaan adalah hasil agregat dari persepsi pemangku kepentingan internal dan eksternal dan berfluktuasi antara positif dan negatif (Leonard, 2018). Ada pula yang mengatakan bahwa reputasi berbeda tergantung pada kelompok pemangku kepentingan (Mishina et al., 2011); (Bundy et al., 2017).

Penelitian terbaru dalam konteks ini menekankan bahwa kelompok pemangku kepentingan yang berbeda mengevaluasi aspek reputasi yang berbeda (Ertug et al., 2016) dan bahwa pemangku kepentingan yang berbeda membentuk penilaian yang berbeda pada atribut yang sama berdasarkan keyakinan mendasar mereka (West et al. 2016). 
Beberapa penelitian mengangkat topik tentang krisis pada perusahaan yang telah mempertimbangkan sejumlah hasil krisis yang penting, termasuk persepsi pemangku kepentingan tentang reputasi, kepercayaan, dan legitimasi organisasi seperti yang dilakukan oleh (Nwogwugwu, 2018). Salah satu hasil penelitian yang dilakukan Gillespie mengatakan bahwa dalam krisis terdapat ketegangan antara kebutuhan untuk "respons cepat" dan waktu yang dibutuhkan untuk memastikan "proses yang sesuai" (Gillespie, 2018). Memprioritaskan risiko kecepatan tidak menghargai semua faktor yang berkontribusi terhadap kegagalan, mengakibatkan tindakan dangkal yang mengatasi gejala, tetapi bukan penyebabnya. Namun, respons yang terlalu lambat kemungkinan besar akan menimbulkan frustrasi dan sinisme serta risiko meninggalkan penyebab kegagalan tetap ada. Oleh karena itu, respon cepat menjadi sangat penting mengingat krisis bukan sesuatu yang dapat diprediksi akibatnya terhadap perusahaan. Standar menyeluruh untuk proses perbaikan kepercayaan adalah akurasi dan transparansi (Gillespie, 2018). Sebuah contoh kasus besar yang menjadi sorotan dunia mengenai komunikasi krisis adalah perusahaan British Petroleum (BP) yang mengalami insiden tumpahan minyak mentah di Teluk Meksiko sekitar satu dekade lalu. Krisis ini tentu sangat memengaruhi reputasi
BP dan merusak kinerja keuangan perusahaan. Selain itu, yang tidak kalah penting adalah akibat dari krisis ini terjadilah perubahan yang ekstrim pada hubungan perusahaan dengan para pemangku kepentingan seperti konsumen, pemerintah, masyarakat lokal dan karyawan. Insiden ini memberikan banyak dampak mulai dari mengancam ekosistem laut dan darat karena tercemar minyak mentah dan membuat ekonomi masyarakat sekitar Teluk Meksiko kehilangan mata pencaharian sebagai nelayan.

BP merupakan Perusahaan minyak dan gas besar yang dikenal dunia dan memiliki Public Relations yang terkenal kuat. Namun, ketika terjadi krisis yang mengakibatkan geger di dunia perminyakan, strategi penanganan komunikasi BP tidak tepat. Spokeperson yang ditunjuk BP tidak dapat menenangkan publik dengan memberikan statement awal yang tidak faktual dan menjanjikan kompensasi pada para pemangku kepentingan yang terdampak. Profesor Komunikasi dari University of Kentucky Amerika Serikat, Timothy Sellnow mengatakan bahwa upaya yang dilakukan PR BP didapatkan dari pengalaman Exxon terdahulu, namun informasi yang disampaikan spokeperson BP tidak efektif. Ahli lain, seorang Profesor Emeritus di Syracuse University, John Philip Jones menyebut tindakan yang dilakukan PR BP sebagai bencana Public Relations karena banyak media massa yang mencederai reputasi 
BP dan memberi tekanan untuk menyediakan kompensasi sebesar 20 Miliar Dolar AS kepada penduduk terdampak bencana terutama yang terkena dampak ekonomi (Koswara, 2014).

Berkaca pada kasus BP tersebut, tidak dapat dipungkiri bahwa penanganan pada kemunculan sebuah krisis tidak dapat dianggap sepele. Tim manajemen krisis BP memiliki persiapan dan prosedur krisis yang sangat baik, namun ketika terjadi krisis, tim komunikasi krisis tidak dapat melakukan respons dengan baik. Ditambah lagi, ketika BP menghadapi krisis, dunia sudah memasuki era digital, di mana berita cepat sekali menyebar dalam platform yang dinamakan media sosial. Untuk itulah peran PR sebagai garda terdepan komunikasi krisis perusahaan dalam proses manajemen krisis menjadi sangat penting.

Austin \& Jin mendefiniskan komunikasi krisis sebagai "lies in the strategic goal of enabling an organization to diminish thenegative consequences (e.g., negative perceptions, reputation damage, and uncertainty)" (Austin \& Jin, 2017). Dalam bahasa Indonesia, komunikasi krisis diartikan sebagai tindakan yang terletak pada tujuan strategis yang memungkinkan organisasi untuk mengurangi konsekuensi negatif(misalnya, persepsi negatif, kerusakan reputasi, dan ketidakpastian). Sebuah pengelolaan informasi yang efektif sangatlah krusial bagi sebuah perusahaan. Hal ini berkaitan dengan alur komunikasi penyampaian pesan esensial bagi para pemangku kepentingan yang relevan. Komunikasi krisis berfokus pada mengembangkan strategi retorika yang bertujuan untuk meminimalisir kesalahan dan membantu organisasi, terutama perusahaan, dalam mengembalikan kegiatan rutin dengan resiko kerusakan reputasi yang minimal (Coombs, 2015). Sebagai salah satu bagian paling penting dalam manajemen krisis perusahaan, PR mengawal dengan ketat komunikasi krisis pada setiap fase krisis. Fase krisis terbagi atas pre-krisis, fase saat krisis dan fase pasca-krisis. Pada setiap fase krisis terdapat sub-fase krisis yang mencakup kegiatan apa saja yang dilakukan pada masing-masing fase krisis (Coombs, 2015). Pada tahap pre-krisis terdapat beberapa tahap seperti: (1) deteksi sinyal, (2) pencegahan, dan (3) persiapan krisis (Coombs, 2015). Selama masa krisis, perusahaan harus mengambil 2 (dua) tindakan yang tepat, yaitu: (1) pengenalan krisis dan (2) pembatasan krisis. Ketika suatu krisis telah berakhir dan dianggap telah terlewati, perusahaan harus mempertimbangkan tindakan pasca-krisis yang harus dilakukan dengan tujuan (a) mempersiapkan perusahaan dalam menghadapi kemungkinan krisis berikutnya, (b) memastikan pemangku kepentingan mendapatkan kesan positif terhadap upaya penanganan krisis organisasi, dan (c) memeriksa untuk memastikan 
bahwa krisis benar-benar berakhir (Coombs, 2015). Seperti kasus BP yang telah dibahas di atas, selain ancaman di dunia nyata, kehadiran media sosial telah menambah ancaman krisis dalam dunia online. Munculnya teknologi media baru dan adopsi platform media sosial telah mengubah cara organisasi berkomunikasi dengan para pemangku kepentingan (Derani \& Naidu, 2016).

Keterlibatan media sosial dalam kehidupan manusia terlihat dari jumlah pengguna media sosial aktif di dunia mencapai 3,8 miliar orang (Hotsuite, 2020). Lanskap komunikasi krisis di media sosial organisasi mengalami perubahan setidaknya dalam dua cara penting. Pertama, media sosial dapat menjadi alat untuk membangun reputasi perusahaan. Sebaliknya, media sosial juga dapat merusak reputasi perusahaan seperti dikemukakan dalambeberapa penelitian yang dilakukan para ahli (Horn et al., 2015; Leonard, 2018). Walaupun sebenarnya media sosial sangat popular dan memiliki signifikansi dalam ketahanan perusahaan, bagaimana pendekatan krisis komunikasi perusahaan di lingkungan media sosial belum banyak diketahui (Ki \& Nekmat, 2014). Sebagai adopsi media sosial yang matang, perusahaan harus mengintegrasikan strategi media sosial dengan strategi keseluruhan perusahaan (Aral, 2013). Terdapat penelitian lain yang dilakukan Hosseinali-Mirza, et al mengatakan bahwa media sosial memberikan dampak krisis pada reputasi perusahaan (Hosseinali-Mirza et al., 2015). Penyebaran informasi yang cepat di media sosial menyebabkan dampak krisis muncul dengan cepat dan perusahaan perlu memiliki strategi komunikasi krisis media sosial yang sesuai. Media sosial didefinisikan sebagai "sebuah perangkat elektronik, teknologi, dan aplikasi yang memfasilitasi komunikasi interaktif dan pertukaran konten memungkinkan pengguna untuk bergerak maju dan mundur dengan mudah antara peran audiens dan pembuat konten" (Derani \& Naidu, 2016).

Media sosial merupakan platform yang terbuka, sosial dan berorientasi kepada penggunanya. Hal lainnya adalah pengguna bisa menghasilkan konten, aktual, bersifat pribadi, interaktif dan subjektif karena pengguna dapat membagikan opini atau informasi dengan pengguna lainnya. Media sosial mencakup layanan blog, jejaring sosial, microblogging, forum, berbagi media dan layanan kolaborasi. Contohnya berupa Instagram, Facebook, Youtube dan Twitter, tempat manusia dapat saling berinteraksi meskipun melalui komputer atau perangkat seluler. Secara definisi, media sosial dikatakan sebagai "blog, lingkungan jejaring sosial, pesan siaran orang ke orang dan aplikasi Web 2.0 lainnya" (Voorveld et al., 2018).

Kaitannya dengan krisis pada perusahaan, 
media sosial dapat dikatakan sebagai upaya memperbaiki krisis atau bahkan membuat kondisi krisis lebih buruk (Veil et al., 2011). Oleh karena itu, media sosial dianggap sebagai pedang bermata dua, di satu sisi menyediakan platform dan sarana baru bagi organisasi untuk berkomunikasi dengan pemangku kepentingan, sementara di sisi lain dapat meningkatkan krisis bagi organisasi yang terdampak (Pang et al., 2014). Terlepas dari respons krisis di media tradisional, perusahaan perlu lebih memperhatikan kecepatan dan respons krisis di saluran media tradisional dan media sosial. Penelitian ini melengkapi penelitian yang dilakukan oleh Hosseinali-Mirza yaitu dalam hal strategi komunikasi krisis yang dapat memenuhi tuntutan waktu merespons dan penggunaan media tradisional dan media sosial secara efektif (Hosseinali-Mirza et al., 2015).

Salah satu strategi komunikasi krisis yang melibatkan media tradisional dan media sosial adalah model Komunikasi Krisis Media Sosial (Social Mediated Crisis Communication) atau disingkat SMCC. Model SMCC merupakan model pertama yang diciptakan pada tahun 2010 oleh Jin (Jin et al., 2014). Model (SMCC dan dikembangkan dalam kepentingan pengembangan model empiris dan pengujian yang spesifik untuk membantu membuat keputusan dalam komunikasi krisis, kapan dan dimana harus merespons pengaruh dalam media sosial, disamping juga harus mengakui pengaruh media tradisional dan komunikasi dari mulut ke mulut secara langsung (Austin et al., 2012).

Model SMCC ini merupakan bentuk yang dapat dimanfaatkan secara efektif untuk khalayak sasaran yang berbeda-beda melalui saluran berbeda. Untuk masing - masing jenis pesan berbeda, terdapat saluran pesan yang ideal agar dapat dalam mendukung satu sama lain. Terdapat tiga jenis publik kunci yang menghasilkan dan mengkonsumsi informasi, yaitu influentials social media creators, pembuat dan penyebar informasi di media sosial yang dapat diakses oleh publik. Follower, Individu yang mengikuti akun media sosial. Dan inactive follower, yaitu Individu yang tidak langsung mengakses informasi dari media sosial dan mencari informasi dari sumber lain yang terekspos informasi dari media secara tidak langsung. Adapula offline word-of-mouth (WOM) yang merupakan saluran komunikasi interpersonal digunakan oleh semua publik dalam mengkonsumsi dan membagi informasi krisis. Antara WOM online dan offline, hal yang perlu dicatat adalah publik biasanya lebih terlibat pada WOM offline dengan orang yang memiliki pengaruh kuat pada meraka dibandingkan dengan WOM online. Berikut ini adalah gambar dari model SMCC, pada gambar 1. 


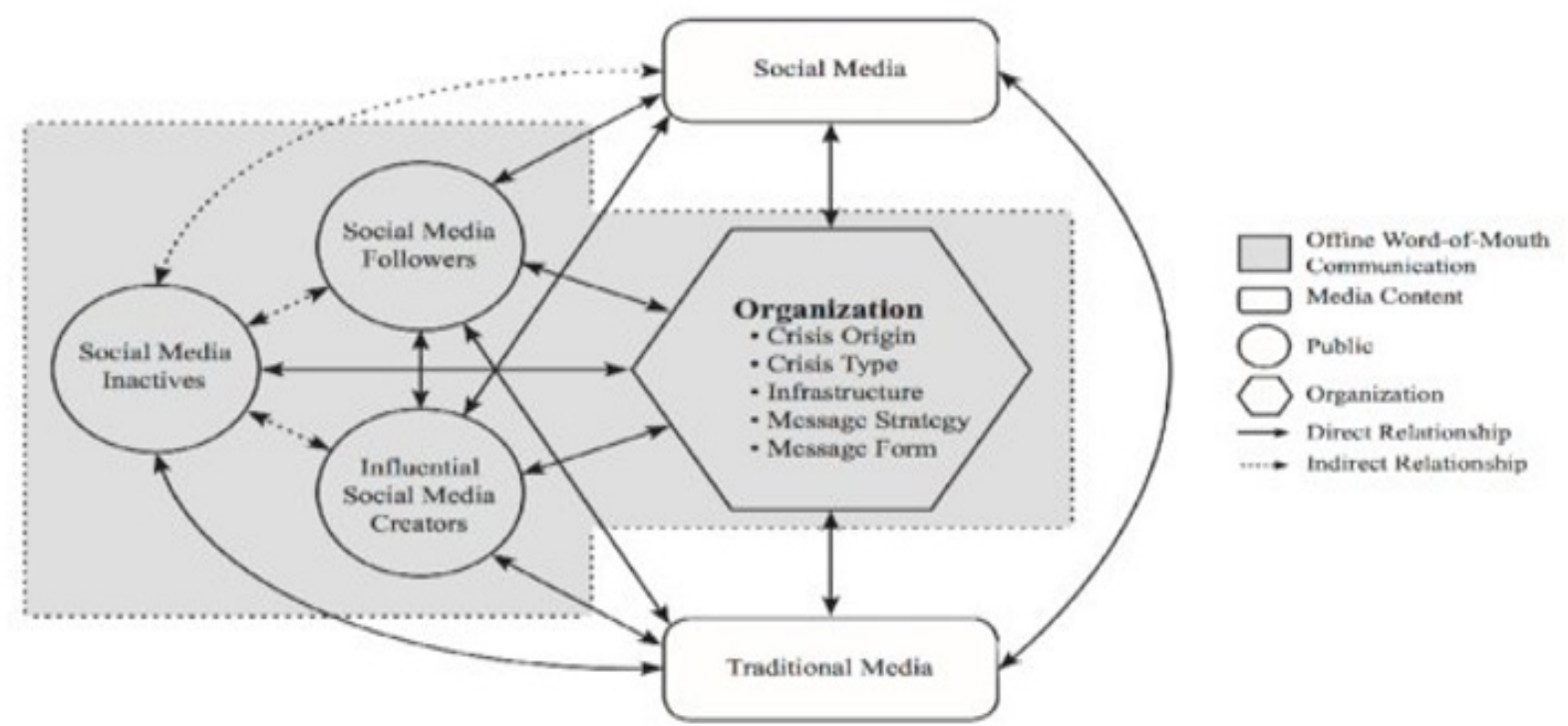

Sumber : Austin, Liu \& Jin, 2012

\section{Gambar 1: Model Social Mediated Crisis Communication (SMCC)}

Terdapat beberapa aspek yang perlu dipertimbangkan dalam menggunakan model ini, Aspek pertama adalah asal krisis, yaitu apakah krisis tersebut adalah krisis internal atau eksternal.

Internal yaitu berasal dari dalam perusahaan, sementara eksternal adalah krisis yang berasal dari luar perusahaan. Aspek kedua adalah jenis krisis. Jenis krisis ada dua yaitu krisis kecil dan krisis besar. Untuk krisis yang kecil, PR bisa meredam hanya sampai ke internal saja dan tidak sampai menjangkau publik luas. Penyelesaian dilakukan ke inti atau ke masalah teknis krisisnya sebelum menyebar. Untuk tipe krisis yang besar, apalagi sampai merambah media sosial, PR perlu melakukan penyelesaian inside out. Melakukan komunikasi krisis internal dan komunikasi krisis eksternal dengan terjun langsung ke inti publik terdampak, melibatkan pihak-pihak yang bisa memperkuat referensi komunikasi krisis dan menyebarkan berita lebih luas lagi.

Jenis krisis yang disarankan oleh Coombs dalam model ini adalah klaster korban (victim cluster) yaitu organisasi dikategorikan ke dalam klaster korban jika publik meyakini bahwa organisasi bukanlah penyebab krisis. Dalam hal ini organisasi dipercaya sebagai korban dari krisis tersebut (Coombs, 2015). Klaster kecelakaan atau tanpa kesengajaan (accidental cluster) muncul ketika publik meyakini bahwa peristiwa yang terjadi bukanlah kesengajaan yang dilakukan oleh organisasi. Dengan kata lain, organisasi tidak mempunyai maksud 
sengaja yang menyebabkan krisis. Yang terakhir, klaster kesengajaan (intentional cluster), terjadi jika organisasi diatribusi sebagai penyebab terjadinya krisis (Coombs, 2015).

Aspek ketiga adalah adalah kesiapan infrastruktur, yaitu mempertimbangkan apakah krisis harus ditangani di tingkat lokal atau perlu ditangani secara terpusat. Penanganan menggunakan pendekatan terpusat, kantor pusat perusahaan menangani komunikasi krisis sedangkan dalam pendekatan lokal ditangani oleh departemen lokal yang terlibat dalam krisis. Kesiapan infrastruktur ini juga harus memperhatikan bagaimana tempat, sumber daya, prosedur dan kemampuan dalam mempraktekkan prosedur pada saat krisis. Prosedur tersebut perlu pengecekan secara berkala perlu dilakukan agar tetap up to date. Aspek keempat adalah strategi pesan (Liu et al., 2012). Pada strategi ini teori Coombs dapat dijadikan panduan. Strategi yang digunakan adalah pesan harus konsisten dan disetujui oleh tim manajemen krisis dan pimpinan tertinggi perusahaan (Coombs, 2015). Aspek yang terakhir adalah bentuk pesan, yang harus dipertimbangkan dengan hati-hati adalah media (Liu et al., 2012). Dikatakan hati-hati mengingat bahwa media tidak dapat dikendalikan, sehingga perusahaan harus memilih media yang tepat untuk menyampaikan pesan krisis. Hal yang perlu dipertimbangkan adalah memilih media berdasarkan asal datangnya krisis, sehingga dapat langsung ke akar penyebaran krisisnya.

Aspek lain yang perlu dipertimbangkan adalah hubungan antara berbagai pihak yang menafsirkan dan berbagi informasi bersifat langsung atau tidak langsung. (Liu et al., 2012) mengemukakan bahwa media sosial membuat pihak ketiga atau yang ditunjukkan sebagai influentials pada diagram membawa pengaruh signifikan dalam suatu krisis sehingga dapat bermanfaat untuk diajak bekerja sama. Hal ini sejalan dengan saran (Veil et al., 2011), bahwa perusahaan harus bekerja sama dengan para pemimpin opini (Key Opinion Leader) agar mereka dapat bertindak sebagai sekutu perusahaan dalam suatu krisis.

Secara definisi Key Opinion Leader (KOL) adalah tokoh yang aktif di jejaring sosial, suka berbagi ide dengan orang lain dan mampu menarik perhatian dan memengaruhi ide serta perilaku orang lain. Identifikasi KOL telah mendapat banyak perhatian karena bisa menjadi kuat dalam memasarkan dan mengarahkan opini publik (Zhao \& Kong, 2017). Karakteristik KOL dapat dilihat sebagai berikut: KOL dapat ditemukan di setiap tingkat sosial dan di sebagian besar bidang pengambilan keputusan, KOL memengaruhi orang-orang dari tingkat sosial yang sama, KOL cenderung lebih terlibat dalam berbagai kegiatan sosial dan organisasi sosial serta menempati posisi sentral dalam 
jaringan pribadinya, KOL dianggap ahli di bidangnya, KOL cenderung monomorfik: yaitu biasanya ahli di satu bidang tetapi jarang di berbagai bidang (polimorf). KOL mewujudkan perilaku komunikasi tertentu: mereka lebih terlibat dalam komunikasi pribadi formal dan informal daripada non-pemimpin. KOL biasanya sangat sadar bahwa mereka adalah sumber informasi dan pengaruh bagi orang lain (Winter \& Neubaum, 2016). Contoh KOL di media sosial adalah buzzer, influencer dan endorser.

Pemaparan di atas membawa penelitian ini kepada pertanyaan penelitian tentang: (1) bagaimana peran $K O L$ dalam pada strategi komunikasi krisis yang dipilih PR perusahaan sesuai dengan model Social Mediated Crisis Communication?(2)Bagaimanapengaruhwaktu respons yang cepat dari komunikasi krisis yang dilakukan PR pada saat krisis muncul terhadap keberhasilan krisis komunikasi? (3) Bagaimana bentuk dan cara menyampaikan pesan yang efektif kepada publik di saat terjadi krisis? Dengan dijabarkannya pertanyaan penelitian ini, maka akan menghasilkan tujuan penelitian yaitu untuk memahami bagaimana peran KOL pada strategi komunikasi krisis yang dipilih PR perusahaan sesuai dengan model SMCC. Selain itu penelitian ini juga bertujuan untuk mendapatkan pengetahuan mendalam tentang bagaimana pengaruh waktu respons yang cepat dari komunikasi krisis yang dilakukan PR pada saat krisis muncul terhadap keberhasilan krisis komunikasi. Satu hal yang tidak kalah penting yaitu untuk mengetahui bagaimana bentuk dan cara penyampaian pesan yang efektif untuk disampaikan kepada publik agar dapat meraih kepercayaan publik pada saat krisis.

\section{METODE PENELITIAN}

Untuk dapat menjawab pertanyaan penelitian, peneliti menggunakan metode penelitian dengan pendekatan kualitatif dan jenis penelitian deskriptif. Penelitian kualitatif adalah suatu pendekatan untuk mengeksplorasi dan memahami makna yang diberikan oleh individu atau kelompok untuk masalah sosial atau manusia (Creswell, 2014). Terdapat definisi lain penelitian kualitatif yaitu sebagai penelitian yang bertujuan untuk memperoleh karakter yang komprehensif dan menonjolkan fenomena realitas (Mohajan, 2018). Penelitian kualitatif memiliki karakter sifat induktif dan mengeksplorasi mengenai makna dan wawasan dalam situasi tertentu (Levitt et al., 2017). Proses penelitian melibatkan pertanyaan dan prosedur yang muncul, data yang biasanya dikumpulkan dalam setting partisipan, analisis data yang dibangun secara induktif dari tema khusus ke tema umum, dan peneliti membuat interpretasi makna data.

Penelitian deskriptif digunakan untuk 
menjawab pertanyaan bagaimana dan untuk mendapatkan gambaran yang lengkap mengenai peran KOL dalam strategi komunikasi krisis PR perusahaan, pengaruh waktu respons yang cepat dari komunikasi krisis yang dilakukan PR pada saat krisis muncul terhadap keberhasilan krisis komunikasi, serta bentuk dan cara menyampaikan pesan yang efektif kepada publik di saat terjadi krisis.

Dalam sebuah penelitian, sangat penting menentukan paradigma. Menurut Denzin, paradigma berkaitan dengan prinsip-prinsip dasar (Denzin \& Lincoln, 2018). Paradigma merupakan konstruksi manusia. Paradigma menentukan pandangan dunia peneliti. Keyakinan-keyakinan ini tidak akan pernah dapat ditetapkan dari sudut nilai kebenarannya yang tertinggi. Perspektif, sebaliknya, tidaklah seutuh atau sepadu paradigma, meskipun sebuah perspektif bisa jadi sama-sama mengandung banyak elemen dengan sebuah paradigma, seperti rangkaian umum komitmen metodologis (Denzin \& Lincoln, 2018). Penelitian ini menggunakan paradigma post positivistik karena pada paradigma ini peran serta subjek menentukan ada tidaknya realitas yang akan digunakan untuk membawa pemahaman mengenai strategi komunikasi PR menggunakan KOL pada komunikasi krisis perusahaan ke tingkat yang lebih mendalam (Salminen, 2017). Objek penelitian ini adalah KOL pada strategi komunikasi krisis perusahaan.

Pengumpulan data dalam penelitian ini menggunakan in-depth interview sebagai data primer serta jurnal dan buku yang berkaitan dengan topik komunikasi krisis PR perusahaan sebagai data sekunder. Subjek penelitian berjumlah tiga orang informan yang dipilih menggunakan teknik purposive sampling. Kriteria informan sesuai dengan tujuan penelitian yaitu praktisi PR perusahaan yang pernah mengalami komunikasi krisis dan menggunakan KOL sebagai salah satu bagian dari proses komunikasi krisis di perusahaan. Informan memiliki pengalaman minimal 25 tahun di berbagai industri, sehingga sangat kompeten untuk membahas mengenai komunikasi krisis yang merupakan bagian dari pekerjaan PR di perusahaan.

Informan secara sadar dan aktif bersedia untuk diwawancara oleh peneliti, namun karena keterbatasan aktivitas akibat Pandemi Covid-19, maka wawancara tidak dilakukan face-toface, melainkan secara online menggunakan aplikasi Whatsapp call ataupun video call. Proses wawancara ketiga informan dilakukan secara terpisah pada periode 27 Mei - 1 Juni 2020 berlokasi di Jakarta. Wawancara online harus diperlakukan sebagai pilihan yang layak untuk peneliti daripada hanya sebagai pilihan alternatif atau sekunder ketika wawancara tatap muka tidak dapat dicapai” (Nehls et al., 2015). 
Untuk menciptakan kredibilitas penelitian, maka dilakukan triangulasi dengan jalan melakukan cek dan ricek dengan berbagai sumber data di penelitian ini (Creswell, 2014) yaitu in-depth interview dengan ketiga informan serta dokumentasi. Data yang telah dikumpulkan kemudian diolah menggunakan teknik analisis data Grounded Theory, yaitu teori yang diturunkan dari data, dikumpulkan dan dianalisis secara sistematis melalui proses penelitian (Creswell, 2014). Dalam metode ini, pengumpulan data, analisis, dan teori akhirnya berdiri dalam hubungan yang erat satu sama lain (Creswell, 2014). Analisis data pada grounded theory dilakukan dengan proses coding (Bryman, 2012). Dengan tahapan-tahapan sebagai berikut: Penulis melakukan transkrip terhadap semua hasil wawancara informan, Melakukan open coding, yaitu memecah data transkrip wawancara informan dan memberikan label pada data sekaligus kode pada masingmasing data. Berikutnya mengelompokkan data-data dengan ide yang sama dalam suatu kategori, Melakukan axial coding, yaitu mengatur pembagian Data yang telah dikelompokkan, diatur pembagiannya sesuai dengan urutannya atau sehingga menjadi benar dan terarah, lalu memasukkannya ke dalam suatu pola kategori dan satu uraian bergantung perkembangan data yang diperoleh, melakukan selective coding, yaitu memilih kategori inti dan menghubungkannya dengan kategori lain. Kemudian memvalidasi hubungan tersebut dan mengisi kategori yang perlu perbaikan dan pengembangan lebih lanjut. Hasil coding berupa narasi dengan alur cerita sebagai dasar laporan analitis penelitian ini. Setelah semua selesai, maka dilakukan penulisan laporan yang disajikan ke dalam artikel jurnal ini.

\section{HASIL DAN PEMBAHASAN}

In-depth Interview terhadap ketiga informan dalam penelitian ini menghasilkan beberapa temuan yang akan dijabarkan dan dianalisa pada bagian ini. Semua informan menjelaskan proses komunikasi krisis berdasarkan pengalaman yang telah dialami terkait komunikasi krisis di perusahaan masing-masing. Terdapat tiga pertanyaan pada penelitian ini sebagai panduan untuk mendeskripsikan hasil dan pembahasan. Pertanyaan pertama adalah bagaimana peran KOL dalam membantu PR pada strategi komunikasi krisis yang dipilih PR perusahaan sesuai dengan model Social Mediated Crisis Communication?. Untuk menjawab pertanyaan ini, pertama-tama peneliti menyelidiki krisis berdasarkan asal, jenis, infrastruktur, strategi pesan dan bentuk pesan atau saluran penyebaran informasi. Krisis bisa berasal dari berbagai sumber, seperti: pemangku kepentingan, perusahaan lain, dan media arus utama. 
Penyebab krisis juga beragam, bisa jadi karena kesalahan organisasi atau kesalahan pemangku kepentingan atau bisa juga karena kesalahan pada operasional di lapangan. Saluran yang digunakan untuk menyebarkan informasi bisa berupa media tradisional, media sosial dan media lainnya. Informan pertama membagi pengalamannya saat menghadapi krisis sebagai berikut:

"Saya pernah mengalami krisis sampai nama saya masuk ke koran. Ada satu LSM yang menuduh Perusahaan melakukan pencurian minyak di daerah Sumatera. Tuduhannya adalah perusahaan terlibat dalam pencurian minyak tersebut, jadi setiap minyak diantar dari lapangan ke tempat penampungan minyak itu selalu ada yang berkurang. LSM ini mendapatkan informasi dari salah satu orang yang merupakan pihak internal perusahaan." (B, 27 Mei 2020, interview pribadi).

Peneliti mengidentifikasikan terlebih dahulu aspek-aspek dalam krisis yang terjadi. Asal krisis berasal dari internal perusahaan yang menyampaikan berita ke luar yaitu LSM. Oleh karena itu, asal krisis ini adalah internal. Jenis krisis termasuk dalam Cluster victim. Hal ini karena perusahaan adalah korban dari penyebaran berita atau rumor yang belum tentu benar. Infrastruktur krisis ada pada tingkat lokal. Strategi pesan yang dipilih adalah menyampaikan berita yang sebenarnya, tentunya dengan melakukan investigasi dan menginstruksikan masyarakat bila ada buktibukti yang mendukung untuk melaporkan ke perusahaan. Bentuk pesan yang dipilih adalah menggunakan media yang sama dengan yang digunakan untuk membuat krisis yaitu media tradisional.

Sejak kemunculan krisis pertama yaitu pada saat berita muncul di media tradisional yaitu surat kabar, perusahaan langsung bergerak ke lapangan tempat terjadinya tuduhan pencurian minyak dan penyebar berita. PR langsung mengadakan mediasi kepada pihak-pihak terkait seperti terduga penyebar berita, LSM yang mendukung penyebar berita tersebut, karyawan di lokasi, masyarakat sekitar, polisi, wartawan dengan tujuan untuk menyampaikan klarifikasi berita.

"Sebelum merebak ke media sosial, kita datangi langsung ke masyarakat sekitar lapangan minyak. Karena kasusnya adalah pencurian, maka diturunkan polisi untuk mengawal dan melakukan pengecekan di jalan untuk membuktikan. Lalu terjadi demo yang menuduh kita merusak jalan umum. Pihak yang menuduh tetap ingin melanjutkan kasus ini dan memanggil wartawan. Hasil investigasi dijalan menyatakan bahwa tidak ada pencurian. (B, 27 Mei 2020, interview pribadi)

Masyarakat melakukan demo yang memblokade jalan menuduh perusahaan melakukan pencurian dan membuat jalan rusak. Demo tersebut diwarnai emosi yang memunculkan keributan. PR perusahaan meminta bantuan tokoh masyarakat sekitar. Tokoh masyarakat tersebut di dalam model SMCC termasuk dalam kategori influentials 


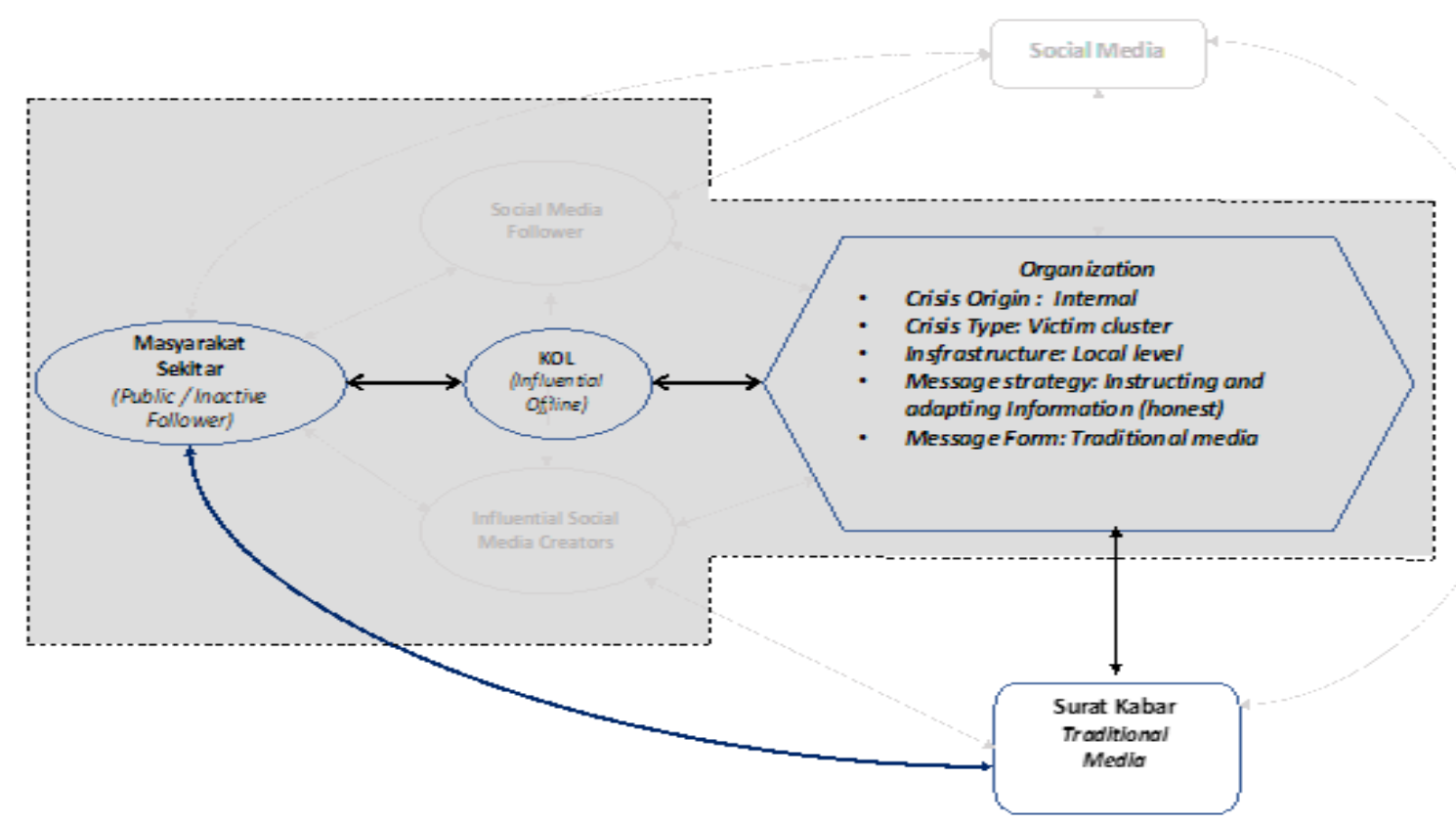

Sumber: Hasil olahan peneliti, 2020

Gambar 2 Model Social Mediated Crisis Communication (SMCC) Hasil Peneliti

atau KOL. Masyarakat sekitar merupakan inactive follower karena mendapatkan berita dari koran dan dari mulut ke mulut secara offline. Masyarakat merasa menjadi korban terdampak krisis dan menuntut perusahaan untuk bertanggung jawab. Tujuan PR meminta bantuan KOL untuk menjadi jembatan komunikasi perusahaan dengan masyarakat untuk meneruskan informasi lengkap yang diberikan PR Perusahaan. Hal ini karena PR merasa tidak mungkin akan didengarkan oleh masyarakat yang sedang emosi. PR memberikan berita klarifikasi kasus ini ke surat kabar sambil meminta masyarakat untuk melaporkan jika ada kecurigaan pencurian minyak di lapangan, sesuai pernyataan Informan berikut:
"Kami mengundang wartawan untuk melakukan klarifikasi. Kami juga meminta masyarakat untuk melaporkan kalau memang ada bukti keterlibatan perusahaan dalam pencurian dan dapat. Perusahaan dibantu tiga tokoh kuat di masyarakat setempat yaitu tokoh agama, tokoh pejabat setempat dan tokoh dominan atau yang disegani. Tokoh ini membantu dalam hal komunikasi kepada masyarakat ketika perusahaan sulit melakukan komunikasi kepada masyarakat. Kuncinya kalau kita sudah dibantu tokoh ini, penyelesaian masalah akan smooth banget." (B, 27 Mei 2020, interview pribadi).

Pernyataan informan tersebut didukung

oleh peryataan dari informan lainnya yaitu:

"Ketika krisis terjadi misal tentang lingkungan, pihak perusahaan sebaiknya melibatkan Dinas Lingkungan dari kabupaten, Pusat Studi Lingkungan dari Universitas Negeri setempat untuk membantuperusahaan dalam halmengasses. Hal ini membantu pembentukan opini 
publik tentang perusahaan bertanggung jawab dan bisa dipertanggungjawabkan karena ada keterlibatan orang lain yang kompeten di sana." (A, 1 Juni 2020, interview pribadi).

Contoh kasus tuduhan pencurian minyak yang menjadi berita di surat kabar terjadi pada industri minyak dan gas. Industri minyak dan gas di Indonesia belum memanfaatkan media sosial sebagai media utama komunikasi krisis, karena selama ini lebih efektif penyelesaian langsung turun ke masyarakat terdampak krisis (C, 28 Mei 2020, interview pribadi). Selain itu, karena krisis terjadi pada media tradisional dan masyarakat lingkupnya masih di suatu daerah tertentu, maka penggunaan tokoh masyarakat setempat seperti tokoh agama, tokoh pemerintahan dan tokoh berpengaruh yang disegani merupakan pihak eksternal perusahaan lebih didengar dan dipercaya. Apabila terjadi krisis terjadi pada industri lain dapat berbeda penanganan krisisnya tergantung dari saluran komunikasi dominan publik industri tersebut.

Perusahaan merupakan sumber informasi satu-satunya mengenai krisis, segala informasi tentang krisis termasuk klarifikasi hanya dapat dilaksanakan PR dan spokeperson yang ditunjuk. Namun, penggunaan KOL yang berasal dari masyarakat lokal disebabkan karena mereka lebih memahami serta memiliki kemampuan untuk memengaruhi opini publik, sehingga masyarakat akan lebih mendengarkan KOL dibandingkan dengan perusahaan. Temuan ini menarik bahwa KOL dapat juga berada di dunia nyata tidak hanya di online. Sebagai tambahan, KOL dunia nyata bisa juga profesional di bidang tertentu yang bisa dipergunakan perusahaan. Namun, jika kondisinya PR harus menggunakan media sosial sebagai saluran komunikasi krisis, bukan tidak mungkin PR menggunakan jasa KOL seperti buzzer atau influencer.

"Buzzer bisa digunakan untuk krisis. Kalau di industri minyak dan gas sepertinya belum. Hal ini karena di industri oil and gas kalau terjadi krisis biasanya lebih banyak penanganannya ke masalah teknis langsung yang dapat dilakukan secara internal. Namun, untuk industri lain secara general apalagi kalau di dunia politik penggunaan buzzer efektif." . (B, 27 Mei 2020 , interview pribadi).

Sesuai teori yang dikemukakan Austin, organisasi dapat memainkan peran penting sebagai fasilitator penanggulangan krisis dalam situasi di mana publik membutuhkan klarifikasi, informasi, pengurangan ketidakpastian serta perasaan negatif (Austin et al., 2012). PR harus mempertimbangkan untuk menyajikan informasi lebih lanjut dan bahkan bermitra dengan publik dan pihak ketiga untuk mengatasi situasi krisis secara kolektif. Namun, implementasi komunikasi krisis kemitraan ini harus merupakan bagian dari strategi manajemen krisis perusahaan yang disetujui oleh manajemen. Hal ini sangat penting karena meskipun menggunakan pihak ketiga, PR harus 
dengan sangat hati-hati dan memantau secara dekat pelaksanaan strategi ini. Tujuannya agar informasi yang disampaikan ke publik merupakan informasi dari perusahaan yang sudah disetujui PR dan manajemen.

\section{Perusahaan}

perlu

selalu

mempertimbangkan dengan hati-hati respons krisis dan waktu merespons. Terlepas dari pesan respons krisis tradisional, perusahaan perlu juga memperhatikan kecepatan dan saluran respons krisis di lingkungan media sosial. Memilih saluran respon krisis haruslah mempertimbangkan jangkauan kepada stakeholders yang mana yang paling terdampak, agar pesan krisis bisa diterima stakeholders tersebut untuk memenuhi kebutuhan informasi lebih lanjut akan dampak yang mungkin akan mencapainya.

Pernyataan di atas terkait juga dengan pertanyaan kedua dari penelitian ini yaitu bagaimana pengaruh waktu respons yang cepat dari komunikasi krisis yang dilakukan PR pada saat krisis muncul terhadap keberhasilan krisis komunikasi? Pada saat awal terjadi sebuah krisis, PR harus mengambil peran sebagai penanggung jawab komunikasi perusahaan sebagai bagian dari manajemen krisis. PR mencoba mendapatkan informasi krisis mengenai kejadian lengkap di lapangan. Kemudian, PR berkoordinasi dengan seluruh lini perusahaan harus sesegera mungkin melakukan tindakan komunikasi sebagai respons pertama kali kepada publik yang berupa konferensi pers sejam setelah krisis terjadi. Konferensi pers mencakup statement kepada stakeholders dan yang terdampak krisis tentang informasi awal tentang krisis yang terjadi. Informasi berisi detail krisis, penanganan pertama, teknis penyelesaian serta bagaimana mengurangi dampak terhadap masyarakat. Terdapat ideal time atau golden hours bagi PR melakukan respons pertama kali saat krisis muncul. Hal ini sesuai dengan keterangan informan ketiga, yaitu:

"12 jam awal menentukan seberapa level kualitas atau kompleksitas dari publik melihat krisis. Kemudian orang bersepakat mengatakan bahwa kita harus betul-betul mempersiapkan 12 jam awal, atau disebut prime hournya PR untuk melakukan kegiatan komunikasi. Dalam hal komunikasi krisis, karena belum tentu kita punya informasi yang cukup dalam 12 jam pertama, biasanya hal paling penting dan dibutuhkan masyarakat adalah tanggung jawab perusahaan. Hal ini diperlihatkan dengan statement awal, walaupun hanya dengan menyatakan bahwa iya benar ada persoalan." (A, 1 Juni 2020, Interview pribadi)

Informan satu mengkonfirmasi mengenai prime time ini, sebagaimana disampaikan berikut ini:

"Betul, penanganan krisis sekarang ini maksimal harus 12 jam sejak kemunculan pertama. Kalau tidak dampaknya bisa lebih rumit dan sampai kemana-mana. Karena setiap orang bisa membuka medsos setiap saat. Berita yang ada di medsos baik yang bagus maupun tidak akan ditelen saja tidak melihat lebih detail dan melakukan 
komparasi ke daerah lain. Jadi kalau krisis muncul, harus cepat ditangani jangan sampai dibiarkan dan hari besoknya beritanya ter blow-up." (B, 27 Mei 2020, interview pribadi)

Dalam merespons sebuah krisis, Prastya mengingatkan bahwa perusahaan memiliki peluang media yang sempit, mulai dari 40 menit hingga maksimal 12 jam untuk memberikan klarifikasi mengenai krisis versi perusahaan (Prastya, 2011). Jika mereka tidak mengumumkan informasi yang relevan dalam jangka waktu ini, publik dapat mengabaikan kredibilitas informasi yang disampaikan dan menghilangkan kepercayaan publik terhadap perusahaan.

Ahli lainnya yaitu Williams mencatat bahwa urgensi pada fase respons krisis menempatkan sistem dan proses komunikasi normal organisasi di bawah tekanan tambahan yang sangat besar. Pengawasan harus dilakukan secara intensif dalam hitungan menit, jam, hari, sementara resiko kerusakan langsung tetaplah ada (Williams et al., 2017). Karakteristik krisis pada tahap ini termasuk urgensi pembuatan keputusan, kompleksitas, permukaan ambiguitas. Keputusan komunikasi yang tepat dalam tahap respons dapat menyederhanakan tahap pemulihan krisis dengan menahan atau mengurangi krisis. Akhirnya, komunikasi yang efektif dalam tahap respons dapat menyelamatkan nyawa. Hal inilah yang menyebabkan tahap saat terjadi krisis adalah yang paling krusial dibandingkan dengan prakrisis dan pasca-krisis.

Pertanyaan terakhir dari penelitian iniadalah Bagaimana bentuk dan cara menyampaikan pesan yang efektif kepada publik di saat terjadi krisis? Saat krisis, Informasi yang disampaikan haruslah informasi yang jujur, faktual dan memberikan tambahan pemahaman bagi publik. Perusahaan menganggap bahwa perlu membuat masyarakat mengerti mengenai selukbeluk permasalahan krisis dan penanganannya. Tujuannya agar berita yang beredar tidak menjadi simpang siur dan publik mendapatkan ketenangan untuk menerima kondisi krisis. Informasi pertama dapat disampaikan konferensi pers dengan mengundang media televisi, mengunggah informasi di website resmi atau di media sosial. Berikut kutipan dari wawancara Informan kedua:

"Secara general, misal terjadi krisis lewat media sosial Youtube, perusahaan harus memberikan koreksi menggunakan media youtube juga. Ada berita yang jelek, perusahaan mengencounter berita yang tersebut dengan berita yang benar, untuk menjelaskan suatu berita yang menyebabkan krisis tersebut." (C, 28 Mei 2020, interview pribadi).

Isi pesan yang disampaikan perusahaan kepada publiknya sangat berpengaruh terhadap penyelesaian krisis, seperti penuturan informan 
berikut:

Pesan krisis yang disampaikan harus honest, konsisten dan bertahap yaitu menggunakan informasi sebelumnya untuk menjadi dasar untuk memberikan informasi bahwa saat ini seperti ini. Jika hal ini dilakukan, akan kelihatan menjadi sebuah historis. Proses ini kita sebut strategi storytelling. Apa karakter media sosial, media sosial itu sangat emosional, jadi sebetulnya apa lawannya emosional customer, emotional readers atau pengguna media sosial ya storytelling, cara melawannya adalah dengan story berdasarkan honesty dan faktual. Cara penyampaian storytelling bukan hanya sekedar data, karena orang itu butuh cerita." (A, 1 Juni 2020, interview pribadi).

PR perusahaan harus memiliki strategi pesan yang terstruktur dengan memperhatikan sifat informasi yang harus jujur, faktual, memperkaya informasi atau sequential. Konten mencakup informasi historis krisis tentang kejadian, penanganan, perkembangan setiap fase penanganan dan informasi kegiatan pasca krisis perusahaan. Metode yang dianggap paling baik dalam menyampaikan informasi ini adalah storytelling, yaitu menggunakan metode bercerita secara sequential tadi agar mudah dipahami oleh publik.

Storytelling adalah strategi yang lebih efektif dan lebih kuat bagi organisasi untuk mengelola strategi komunikasi; juga untuk mengelola komunikasi krisis (Eray, 2018). Hal ini dikuatkan oleh Koop yang menekankan bahwa Storytelling perlu menjadi bagian dari program komunikasi krisis organisasi, karena dapat mengurangi stres dan perasaan negatif selama krisis (Kopp et al., 2011).

Seperti dikemukakan oleh Lee bahwa komunikasi krisis harus dilakuan dengan terbuka dan jujur dalam hal tanggung jawab atas krisis, yang juga akan bermanfaat untuk menyampaikan ketulusan yang dapat membantu menjaga kepercayaan publik (Lee \& Jahng, 2020). Mempertahankan kepercayaan selama krisis dapat memberi perusahaan beberapa manfaat nyata seperti mengendalikan dan mengelola krisis.

Dengan melakukan storytelling dalam komunikasi krisis, dapat membantu menaikkan tingkat kepercayaan publik setidaknya mempertahankan tingkat kepercayaan publik terhadap organisasi. Contoh-contoh spesifik dan ilustrasi hidup yang digunakan dalam storytelling juga dapat menampakkan tindakan korektif perusahaan dalam usahanya bergerak maju dari krisis. Cerita umum yang digunakan PR antara lain menceritakan tentang sejarah perusahaan, yang menegaskan kembali misi atau visi organisasi dan termasuk pengalaman pribadi yang mungkin sesuai dengan situasi yang dihadapi publik selama krisis.

Respon krisis storytelling meningkatkan kepercayaan terhadap organisasi dan mengurangi persepsi tanggung jawab krisis dibandingkan dengan respon tanpa storytelling (Lee \& Jahng, 2020). Hal ini menunjukkan 
bahwa pernyataan misi dan visi dapat berfungsi sebagai taktik bercerita yang menarik untuk memanusiakan perusahaan, membantunya mempertahankan kepercayaan dan mengurangi persepsi tanggung jawab selama krisis.

Serupa dengan hasil penelitian Eriksson, sangat penting bagi perusahaan untuk memberikan informasi mengenai krisis secara terbuka dan jujur yang dikonseptualisasikan dalam kontinum (Eriksson, 2018). Hal ini dilakukan untuk mencegah beredarnya informasi yang keliru dan untuk menumbuhkan kepercayaan media dan publik.

Dari pembahasan yang telah dilakukan, ada beberapa catatan PR perusahaan, antara lain komunikasi krisis harus dilakukan secara menyeluruh yaitu internal dan eksternal. PR melakukan pendekatan kepada internal agar dapat menenangkan karyawan di perusahaan dan mengatur laju informasi yang keluar dari spokeperson yang ditunjuk oleh manajemen dan PR. Untuk komunikasi eksternal, seperti pembahasan di atas, bahwa PR melakukan komunikasi melalui saluran yang dipilih. Kelebihan komunikasi face-to-face dengan publik yang terdampak langsung sangat efektif untuk mengurangi resiko langsung yang mereka rasakan, termasuk secara emosional karena merasa perusahaan memiliki kepedulian kepada publik. Sementara kelebihan komunikasi media sosial adalah publik dapat langsung berinteraksi dengan perusahaan lewat virtual.

Pada fase pasca-krisis, PR harus melakukan evaluasi terkait proses penanganan krisis dan merekam semua kejadian untuk diambil pelajaran dan kelemahannya sehingga di masa depan dapat menjadi referensi. Pada fase ini pula PR harus memiliki continuity plan untuk memperbaiki imagenya agar kembali seperti semula.

\section{SIMPULAN}

Pada proses komunikasi krisis, terdapat tiga hal yang dapat mendukung keberhasilan komunikasi krisis, yaitu pemilihan strategi respons krisis, short response time dan pemilihan saluran serta pesan mengenai krisis. Saluran informasi krisis harus memperhatikan dimana krisis mencuat. Strategi ini membuat respons tepat sasaran. Pada prosesnya, penggunaan pihak eksternal seperti KOL menjadi penting. KOL pada model SMCC adalah influentials pada media sosial. Namun, temuan menarik dalam penelitian ini adalah KOL seperti tokoh agama, tokoh pemerintahan atau pejabat dan tokoh berpengaruh yang disegani dalam suatu kelompok masyarakat merupakan KOL di dunia nyata yang membantu perusahaan dalam menjalankan komunikasi krisis yang efektif. Di Indonesia, tokoh-tokoh ini masih sering digunakan. Hal ini karena 
publik percaya dengan orang yang berpengaruh, kuat di antara mereka atau dianggap ahli terhadap suatu bidang. Berikutnya, dalam memberikan respons pada krisis, PR harus memenuhi rentang waktu atau prime time untuk memberikan tindakan pertama dari perusahaan tidak boleh lebih dari 12 jam, hal ini penting untuk mendapatkan kepercayaan publik bahwa perusahaan bertanggung jawab dan agar reputasi perusahaan tidak tercoreng. Yang ketiga adalah saluran komunikasi dan pesan tentang krisis. PR harus bisa mempertimbangkan dengan matang saluran komunikasi yang dipilih. Namun, sebaiknya perusahaan mempertimbangkan dengan cermat kualifikasi krisis media sosial, dan menanggapinya dengan strategi khusus yang sesuai dengan persyaratan krisis media sosial, sebagai tindakan pencegahan.

Pesan atau berita krisis yang disampaikan juga harus jujur, faktual dan terbuka. Pesan disampaikan secara historis dan berkala dengan menggunakan metode storytelling. Hal ini agar tercapai tujuan perusahaan untuk dapat menyelesaikan krisis dengan baik dan tetap mendapatkan kepercayaan dari publik sebagai bekal untuk memperbaiki reputasi di masa pasca-krisis.

PR sebaiknya dapat mempersiapkan perusahaan untuk merespons kemungkinan krisis baik di media tradisional maupun di media sosial. Tim komunikasi krisis juga harus bekerja sama dengan tim manajemen krisis perusahaan dalam membuat dokumentasi manajemen krisis mencakup strategi komunikasi krisis penggunaan pihak ketiga atau KOL, waktu respons, pemilihan saluran pesan, dan teknik penyampaian pesan. Yang tidak kalah penting, PR juga harus melakukan simulasi komunikasi krisis secara berkala untuk memantapkan persiapan jika terjadi krisis sebenarnya. Simulasi krisis sangat penting karena dapat sangat bermanfaat dalam melatih koordinasi dan jalur komunikasi ketika terjadi krisis. Kesiapan tim manajemen krisis secara komunikasi krisis maupun perlengkapan lainnya menjadi lebih baik karena sudah terbiasa menjalani simulasi dan selalu diperbarui.

Walaupun penelitian ini memperlihatkan sisi literatur dan data yang berasal dari wawancara mendalam, namun contoh kasusnya hanya di industri migas dan hanya menggunakan media tradisional. Semoga penelitian berikutnya secara komprehensif dapat mengupas perusahaan atau industri lainnya sehingga karakteristik pemilihan strategi komunikasi krisisnya lebih terlihat. Penelitian ini juga tidak terlalu menonjolkan strategi komunikasi media sosial, oleh karena itu diharapkan penelitian berikutnya dapat mengkaji strategi komunikasi krisis perusahaan di media sosial. 


\section{DAFTAR PUSTAKA}

A. (2020). Personal Interview.

Aral, et al. (2013). Social media and business transformation: a framework for research. Information Systems Research, 24, 1.

Austin, L., \& Jin, Y. (2017). Social media and crisis communication. Social Media and Crisis Communication, 1-461. https://doi. org/10.4324/9781315749068

Austin, L., Liu, B. F., \& Jin, Y. (2012). How audiences seek out crisis information: exploring the social-mediated crisis communication model. Journal of Applied Communication Research, 40(2), 188-207. https://doi.org/10.1080/00909882.2012.65 4498

B. (2020). Personal Interview.

Bryman, A. (2012). Social research methods (4th ed.). Oxford University press. http://library1.nida.ac.th/termpaper6/ sd/2554/19755.pdf

Bundy, J., Pfarrer, M. D., Short, C. E., \& Coombs, W. T. (2017). Crises and crisis management: integration, interpretation, and research development. In Journal of Management (Vol. 43, Issue 6). https://doi. org/10.1177/0149206316680030

C. (2020). Personal Interview.

Coombs, W. T. (2014). State of crisis communication: Evidence and the bleeding edge. Research Journal of the Institute for Public Relations, 1(1), 1-12. https:// instituteforpr.org/wp-content/uploads/ CoombsFinalWES.pdf

Coombs, W. T. (2015a). Ongoing crisis communication_planning, managing, and responding-Sage Publications, Inc.

Coombs, W. T. (2015b). Ongoing crisis communication planning, managing, responding (4th ed.). SAGE Publications.
file://C:/Users/youhe/Downloads/ kdoc_o_00042_01.pdf

Creswell, J. W. (2014). Research design qualitative, quantitative, and mixed method approaches. In Journal of Visual Languages \& Computing (4th ed., Vol. 11, Issue 3). SAGE Publications. https:// www.m-culture.go.th/mculture_th/ download/king9/Glossary_about_HM_ King_Bhumibol_Adulyadej's_Funeral.pdf Denzin, N. K., \& Lincoln, Y. S. (2018). The sage habdbook of qualitative research (5th ed.). SAGE Publications.

Derani, N. E. S., \& Naidu, P. (2016). The impact of utilizing social media as a communication platform during a crisis within the oil industry. Procedia Economics and Finance, 35(October 2015), 650-658. https://doi. org/10.1016/s2212-5671(16)00080-0

Eray, T. E. (2018). Storytelling in crisis communication tuğçe ertem eray , University of Oregon, USA. Online Journal of Communication and Media Technologies, 8(2), 131-144.

Eriksson, M. (2018). Lessons for crisis communication on social media: a systematic review of what research tells the practice. International Journal of Strategic Communication, 12(5), 526-551. https:// doi.org/10.1080/1553118X.2018.1510405

Ertug, G., Yogev, T., Lee, Y., \& Hedstrom, P. (2016). The art of representation: how reputation affects success with different audiences in the contemporary art field. Academy of Management Journal, 59(1), 113-134.

Fombrun, C. j. (2018). Reputation realizing value from corporate image. Harvard Business School Press.

Gillespie, N. (2018). Organizational trust repair. The Routledge Companion to Trust, 
September 2015, 284-301. https://doi. org/10.4324/9781315745572

Horn, I. S., Taros, T., Dirkes, S., Hüer, L., Rose, M., Tietmeyer, R., \& Constantinides, E. (2015). Business reputation and social media: A primer on threats and responses. Journal of Direct, Data and Digital Marketing Practice, 16(3), 193-208. https://doi.org/10.1057/dddmp.2015.1

Hosseinali-Mirza, V., De Marcellis-Warin, N., \& Warin, T. (2015). Crisis communication strategies and reputation risk in the online social media environment. International Journal of Business and Social Science, 6(5), 7-21. http://ijbssnet.com/journals/ Vol_6_No_5_May_2015/2.pdf

Hotsuite. (2020). Hotsuite reports digital 2020. https://datareportal.com/reports/digital2020-indonesia

Jin, Y., Liu, B. F., \& Austin, L. L. (2014). Examining the role of social media in effective crisis management: the effects of crisis origin, information form, and source on publics' crisis responses. Communication Research, 41(1), 74-94. https://doi. org/10.1177/0093650211423918

Ki, E. J., \& Nekmat, E. (2014). Situational crisis communication and interactivity: Usage and effectiveness of Facebook for crisis management by Fortune 500 companies. Computers in Human Behavior, 35, 140-147. https://doi.org/10.1016/j. chb.2014.02.039

Kopp, D. M., Nikolovska, I., Desiderio, K. P., \& Gutterman, J. T. (2011). Relaaax, $i$ remember the recession in the early 1980s...": organizational storytelling as a crisis management tool. Computational Complexity, 22(3). https://doi.org/10.1002/ hrdq

Koswara, A. (2014). Komunikasi krisis: analisis upaya respon krisis teluk meksiko dari perspektif public relations. Edutech, 1(1), 107-131.

Lee, H., \& Jahng, M. R. (2020). The role of storytelling in crisis communication: a test of crisis severity, crisis responsibility, and organizational trust. Journalism and Mass Communication Quarterly, 97(4), 981-1002. https://doi. org/10.1177/1077699020923607

Leonard, A. (2018). Corporate reputation risk in relation to the social media landscape. March.

Levitt, H. M., Motulsky, S. L., Wertz, F. J., Morrow, S. L., \& Ponterotto, J. G. (2017). Recommendations for designing and reviewing qualitative research in psychology: Promoting methodological integrity. Qualitative Psychology, 4(1), 2-22. https://doi.org/10.1037/qup0000082

Liu, B. F., Jin, Y., \& Austin, L. L. (2013). The tendency to tell: understanding publics' communicative responses to crisis information form and source. Journal of Public Relations Research, 25(1), 51-67. https://doi.org/10.1080/106272 6X.2013.739101

Liu, B., Jin, Y., Austin, L., \& Janoske, M. (2012). The social-mediated crisis communication model: guidelines for effective crisis management in a changing media landscape. January, (pp. 257-266).

Mikušová, M., \& Horváthová, P. (2019). Prepared for a crisis? Basic elements of crisis management in an organisation. In Economic Research-Ekonomska Istrazivanja (Vol. 32, Issue 1, pp. 1844 1868). https://doi.org/10.1080/133167 7X.2019.1640625

Mishina, Y., Block, E. S., \& Mannor, M. J.(2011). The path dependence of organizational 
reputation: how social judgement influences assessments of capability and character. Business, 33(September), 459-477. https:// doi.org/10.1002/smj

Mohajan, H. K. (2018). Qualitative research methodology in social sciences and related subjects. Journal of Economic Development, Environment and People, 7(1), 23-48.

Nehls, K., Smith, B. D., \& Schneider, H. A. (2015). Video-conferencing interviews in qualitative research. Enhancing Qualitative and Mixed Methods Research with Technology, 140-157. https://doi. org/10.4018/978-1-4666-6493-7.ch006

Nwogwugwu, D. (2018). Influence of crisis communication strategies on stakeholders' perception of organizational reputation: a review of research trends. Journal of Communication and Media Research, 10(2), 125-138.

Pang, A., Hassan, N. B. B. A., \& Chong, A. C. Y. (2014). Negotiating crisis in the social media environment: Evolution of crises online, gaining credibility offline. Corporate Communications, 19(1), 96118. https://doi.org/10.1108/CCIJ-092012-0064

Patrick, L., \& Adeosun, K. (2013). Corporate reputation as a strategic asset. International Journal of Business and Social Science, 4(2), 220-225.

Prastya, N. M. (2011). Komunikasi krisis di era new media dan social media. Jurnal Komunikasi, 6, 1-20.

Salminen, J. (2017). The role of social media in corporate crisis communication.

Veil, S. R., Buehner, T., \& Palenchar, M. J. (2011). A work-in-process literature review: incorporating social media in risk and crisis communication. Journal of Contingencies and Crisis Management, 19(2), 110-122. https://doi.org/10.1111/ j.1468-5973.2011.00639.x

Voorveld, H. A. M., van Noort, G., Muntinga, D. G., \& Bronner, F. (2018). Engagement with social media and social media advertising: the differentiating role of platform type. In Journal of Advertising (Vol. 47, Issue 1, pp. 38-54). https://doi.org/10.1080/00913367. 2017.1405754

Williams, T. A., Gruber, D. A., Sutcliffe, K. M., Shepherd, D. A., \& Zhao, E. Y. (2017). Organizational response to adversity: fusing crisis management and resilience research streams. Academy of Management Annals, 11(2), 733-769. https://doi.org/10.5465/ annals.2015.0134

Winter, S., \& Neubaum, G. (2016). Examining characteristics of opinion leaders in social media: a motivational approach. Social Media and Society, 2(3). https://doi. org/10.1177/2056305116665858

Zhao, F., \& Kong, Y. (2017). Discovering social network key opinion leaders based psychology theory in social. 9, 43-49. 